\title{
Profil Pasien Tuberkulosis Paru dengan Penyakit Ginjal Kronik yang Dirawat di RSUP Prof. Dr. R. D. Kandou Manado Periode Oktober 2017 - Oktober 2018
}

\author{
${ }^{1}$ Michael Putranto \\ ${ }^{2}$ Maarthen C. P. Wongkar \\ ${ }^{2}$ Cerelia Sugeng
}

\author{
${ }^{1}$ Program Studi Pendidikan Dokter Fakultas Kedokteran Universitas Sam Ratulangi Manado \\ ${ }^{2}$ Bagian Ilmu Penyakit Dalam Fakultas Kedokteran Universitas Sam Ratulangi Manado \\ E-mail: mikeputranto@gmail.com
}

\begin{abstract}
Patients with chronic kidney disease (CKD) have increased risk of tuberculosis compared to patients with normal renal function. This is due to impaired cell-mediated immunity, imunosupressive medication, HIV infection, and diabetes mellitus (DM). Uremia is also associated with immunodeficiency in CKD patients due to functional abnormality of neutrophils, reduced $\mathrm{T}$ and $\mathrm{B}$ cell function, and impaired monocyte and monocyte-derived dendritic cell function. This study was aimed to obtain the profile of TB patients associated with CKD at Prof. Dr. R. D. Kandou Hospital Manado This was a descriptive retrospective study using medical record data of CKD patients with TB co-infection within one-year. The results showed that of 1369 CKD patients, 32 patients had coinfection with TB (2.34\%). The majority of patients were males (81\%); $62.5 \%$ were in the age range of 46-65 years old. Most of them worked as agricultural farmer (28\%). Forty-four percent of the patients had CKD stage $5 ; 11$ of them did not undergo dialysis. Most CKD patients were caused by NSAID nephropathy $(65 \%)$. Conclusion: The majority of TB patients associated with CKD were males, aged 45-65 years, and worked as farmers. The major cause of CKD was NSAID nephropathy. Most patients suffered from CKD stage 5, some did not undergo dialysis.
\end{abstract}

Keywords: chronic kidney disease, lung tuberculosis

\begin{abstract}
Abstrak: Pasien dengan penyakit ginjal kronik (PGK) mempunyai peningkatan risiko tuberkulosis (TB) dibanding pasien dengan fungsi ginjal yang normal. Hal ini terkait dengan penurunan cell-mediated immunity, pengobatan imunosupresif, koinfeksi human immunedeficiency virus (HIV), dan diabetes melitus (DM). Uremia juga berhungan dengan imunodefisiensi pada PGK yang disebabkan oleh abnormalitas fungsional dari neutrofil, penurunan fungsi sel $\mathrm{T}$ dan $\mathrm{B}$ dan terganggunya fungsi monosit dan sel dendritik turunan monosit. Penelitian ini bertujuan untuk mendapatkan profil pasien TB paru disertai PGK yang dirawat di RSUP Prof. dr. R. D. Kandou Manado periode Oktober 2017-Oktober 2018. Jenis penelitian ialah deskriptif retroskpektif menggunakan data rekam medik pasien PGK dengan koinfeksi TB paru selama satu tahun. Hasil penelitian mendapatkan 1369 pasien PGK; 32 pasien dengan koinfeksi TB paru (2,34\%). Mayoritas pasien berjenis kelamin laki-laki (81\%), berada pada rentang usia 46-65 tahun (62,5\%), dan bekerja sebagai petani (28\%). Sebesar $44 \%$ dari pasien dengan PGK derajat 5; 11 diantaranya non-dialisis. Paling banyak disebabkan oleh nefropati OAINS (65\%). Simpulan: Mayoritas pasien PGK di RSUP Prof. Dr. R. D. Kandou Manado berjenis kelamin laki-laki, berusia 45-65 tahun, dan bekerja sebagai petani. Penyakit penyebab PGK-nya terbanyak ialah nefropati OAINS. Mayoritas pasien PGK dengan derajat 5, sebagian di antaranya non dialisis.
\end{abstract}

Kata kunci: penyakit ginjal kronik, tuberkulosis paru 
Penyakit ginjal kronik (PGK) sampai saat ini masih menjadi masalah kesehatan global, terdapat pada $5-10 \%$ populasi dunia dan meningkat setiap tahunnya. Berdasarkan Global Burden of Disease Study pada tahun 2015, PGK menempati urutan ke-12 penyebab kematian, dari sekitar 1,1 juta kematian penduduk di dunia. ${ }^{1}$ Berdasarkan data World Health Organization (WHO), pada tahun 2016 angka kematian akibat PGK berkisar 1.168 .339 orang atau sekitar $2 \%$ angka kematian seluruh penyakit. ${ }^{2}$ Insidensi PGK diperkirakan 100 kasus per juta penduduk per tahun di Amerika Serikat pada tahun 1995-1999, dan angka ini meningkat setiap tahunnya. Di negaranegara berkembang, insidensi PGK diperkirakan sekitar 40-60 kasus per juta penduduk per tahun. ${ }^{3}$ Menurut data yang dilaporkan oleh Riset Kesehatan Dasar (Riskesdas) pada tahun 2013, prevalensi PGK di Indonesia sebesar 0,2\% dan untuk Sulawesi Utara sebesar 0,4\%. ${ }^{4}$

Tuberkulosis (TB) masih menjadi salah satu dari 10 penyakit penyebab kematian terbanyak di dunia. World Health Organization melaporkan pada tahun 2017 diperkirakan terdapat 10 juta kasus TB, dimana $90 \%$ ialah orang dewasa (berusia $\geq$ 15 tahun), 64\% laki-laki, dan 9\%-nya ialah penyandang HIV. Indonesia merupakan negara ketiga dengan infeksi TB tertinggi di dunia $(8 \%)$ setelah India $(27 \%)$ dan China (9\%). ${ }^{5}$ Menurut data Riskesdas 2013 prevalensi TB paru di Indonesia sebesar $0,4 \%$ dan untuk provinsi Sulawesi Utara sebesar $0,3 \%{ }^{4}$

Indonesian Renal Registry tahun 2017, melaporkan bahwa dari 20.548 kasus PGK derajat 5 terdapat 184 orang dengan koinfeksi TB $(0,9 \%){ }^{6}$ Pada penelitian yang dilakukan oleh Abdelrahman et al. ${ }^{7}$ di Arab Saudi dilaporkan terdapat $7 \%$ pasien yang didiagnosis tuberkulosis dari 256 pasien PGK dengan hemodialisis. Pasien dengan PGK mempunyai peningkatan risiko TB dibanding pasien dengan fungsi ginjal yang normal. ${ }^{8}$ Hal ini terkait dengan penurunan cell-mediated immunity, pengobatan imunosupresif, koinfeksi human immunodeficiency virus (HIV), dan diabetes melitus (DM). ${ }^{9}$ Uremia juga berhungan dengan imunodefisiensi pada PGK yang disebabkan oleh abnormalitas fungsional dari neutrofil, penurunan fungsi sel $\mathrm{T}$ dan $\mathrm{B}$, serta terganggunya fungsi monosit dan sel dendritik turunan monosit. ${ }^{10-12}$

\section{METODE PENELITIAN}

Jenis penelitian ini ialah deskriptif retrospektif. Pengambilan sampel berdasarkan data rekam medik pasien yang menderita PGK yang dirawat di RSUP Prof. Dr. R. D. Kandou periode bulan Oktober 2017 - Oktober 2018.

\section{HASIL PENELITIAN}

Populasi penelitian ialah pasien dengan PGK yang berobat di RSUP Prof. Dr. R. D. Kandou periode Oktober 2017-Oktober 2018. Sampel ialah pasien PGK dengan koinfeksi TB paru berjumlah 32 pasien $(2,34 \%)$ dari total 1369 pasien yang didiagnosis PGK.

Berdasarkan data rekam medik 32 pasien PGK dengan koinfeksi TB paru didapatkan 26 pasien berjenis kelamin lakilaki $(81,25 \%)$ dan 6 pasien berjenis kelamin perempuan $(18,75 \%)$ (Tabel 1).

Tabel 1. Distribusi pasien berdasarkan jenis kelamin

\begin{tabular}{ccc}
\hline $\begin{array}{c}\text { Jenis } \\
\text { kelamin }\end{array}$ & $\mathbf{N}$ & $\boldsymbol{\%}$ \\
\hline Laki-laki & 26 & 81,25 \\
Perempuan & 6 & 18,75 \\
Total & 32 & 100 \\
\hline
\end{tabular}

Dari hasil penelitian, didapatkan pasien yang berusia 26-35 tahun sebanyak 1 orang $(3,1 \%)$, usia $36-45$ sebanyak 4 orang $(12,5 \%)$, usia 46-55 tahun sebanyak 10 orang $(31,25 \%)$, usia 56-65 tahun sebanyak 10 orang $(31,25 \%)$, dan yang berusia $\geq 66$ tahun 7 orang $(21,9 \%)$ (Tabel 2$)$.

Dari 32 orang pasien PGK yang mengidap TB paru didapatkan 1 orang yang bekerja sebagai buruh $(3,125 \%)$, ibu rumah tangga 5 orang $(15,625 \%)$, pegawai swasta 2 orang $(6,25 \%)$, pekerja lepas 2 orang $(6,25 \%)$, pelayan 1 orang $(3,125 \%)$, petani 9 orang $(28,125 \%)$, pensiunan 2 
orang $(6,25 \%)$, PNS 1 orang $(3,125 \%)$, supir 1 orang $(3,125 \%)$, tukang 2 orang $(6,25 \%)$, tidak bekerja 1 orang $(3,125 \%)$, wiraswasta 3 orang, dan lain lain 2 orang $(6,25 \%)$ (Tabel 3).

Tabel 2. Distribusi Pasien berdasarkan kelompok umur

\begin{tabular}{ccc}
\hline Kelompok usia & $\mathbf{N}$ & $\mathbf{\%}$ \\
\hline $26-35$ & 1 & 3,1 \\
$36-45$ & 4 & 12,5 \\
$46-55$ & 10 & 31,25 \\
$56-65$ & 10 & 31,25 \\
$\geq 66$ tahun & 7 & 21,9 \\
Total & 32 & 100 \\
\hline
\end{tabular}

Tabel 3. Distribusi pasien berdasarkan pekerjaan

\begin{tabular}{ccc}
\hline Pekerjaan & $\mathbf{N}$ & $\mathbf{\%}$ \\
\hline Buruh & 1 & 3,125 \\
Ibu rumah tangga & 6 & 18,75 \\
Pegawai swasta & 2 & 6,25 \\
Pekerja lepas & 2 & 6,25 \\
Petani & 9 & 28,125 \\
Pensiunan & 2 & 6,25 \\
PNS & 1 & 3,125 \\
Supir & 1 & 3,125 \\
Tukang & 2 & 6,25 \\
Tidak bekerja & 1 & 3,125 \\
Wiraswasta & 3 & 9,375 \\
Lain - lain & 2 & 6,25 \\
Total & 32 & 100 \\
\hline
\end{tabular}

Berdasarkan data rekam medis 32 pasien PGK yang mengidap tuberkulosis, didapatkan 10 pasien dengan derajat 3 $(31,25 \%), 8$ pasien derajat $4(25 \%)$, dan 14 pasien derajat $5(43,75 \%) ; 3$ diantaranya melakukan hemodialisis dan 11 orang tidak melakukan hemodialisis (Tabel 4).

Tabel 4. Distribusi pasien berdasarkan derajat penyakit ginjal kronik

\begin{tabular}{ccc}
\hline Derajat & $\mathbf{N}$ & $\mathbf{\%}$ \\
\hline 3 & 10 & 31,25 \\
4 & 8 & 25 \\
$5 \mathrm{ND}$ & 11 & 34,375 \\
$5 \mathrm{D}$ & 3 & 9,375 \\
Total & 32 & 100 \\
\hline
\end{tabular}

Dari data rekam medis pasien penyakit ginjal kronik yang mengidap TB paru jika dikelompokkan berdasarkan penyakit yang mendasari PGKnya didapatkan 5 pasien karena hipertensi nefrosklerosis (15.625\%), 8 pasien karena nefropati yang disebabkan obat anti inflamasi non-steroid (OAINS) (65,625), 4 pasien karena diabetic kidney disease $(12,5 \%), 1$ pasien karena glomerulonefritis $(3,1 \%)$, dan 1 pasien karena nefropati obstruksi $(3,1 \%)$ (Tabel 5).

Tabel 5. Distribusi Subjek berdasarkan penyebab PGK

\begin{tabular}{lcc}
\hline Penyebab PGK & N & \% \\
\hline Hipertensi nefrosklerosis & 5 & 15,625 \\
OAINS Nefropati & 21 & 65,625 \\
Diabetic kidney disease & 4 & 12,5 \\
Glomerulonefritis & 1 & 3,125 \\
Nefropati obstruksi & 1 & 3,125 \\
Total & 32 & 100 \\
\hline
\end{tabular}

\section{BAHASAN}

Tujuan penelitian ini ialah untuk mendapatkan profil TB paru pada pasien PGK. Data penelitian ini didapat dari data rekam medis pasien PGK di RSUP Prof. Dr. R. D. Kandou Manado periode Oktober 2017-2018, dengan angka PGK koinfeksi TB paru ialah 32 (2,34\%) dari total 1369 pasien PGK yang dirawat.

Berdasarkan hasil penelitian, infeksi TB paru pada pasien PGK mayoritas terjadi pada laki-laki $(81,25 \%)$. Pada penelitian yang dilakukan oleh Dobler et al. ${ }^{14}$ di Kanada insidensi TB pada pasien PGK juga lebih banyak terjadi pada laki-laki dibanding perempuan $(51 \%)$. Hal yang selaras juga terjadi pada penelitian yang dilakukan oleh $\mathrm{Hu}$ et al. ${ }^{15}$ di Taiwan yaitu $52 \%$ dari kasus terjadi pada laki-laki. Hal ini dikarenakan jenis kelamin laki-laki merupakan salah faktor risiko infeksi tuberkulosis dan juga hal itu dapat dikaitkan dengan kebiasaan merokok yang lebih tinggi pada laki-laki. ${ }^{16-18}$

Pada penelitian ini didapatkan bahwa mayoritas pasien PGK yang terinfeksi TB paru ialah pasien lansia dengan rentang usia sekitar 46-65 tahun (62,5\%). Li et al. ${ }^{19}$ juga melaporkan bahwa insiden TB pada PGK rata-rata terjadi pada lansia $(59,7$ tahun). Penelitian di Turki juga melaporkan 
rata-rata insidensi $\mathrm{TB}$ pada pasien $\mathrm{PGK}$ juga terjadi pada lansia $(45,7$ tahun $) .{ }^{20} \mathrm{Hal}$ ini disebabkan hilangnya jaringan limfoid pada pasien lansia disertai dengan penurunan fungsi imun, yang disebut sebagai penuaan imun immunesenescence.$^{21-23}$ Pada pasien lansia juga dapat terjadi penurunan tingkat respon imun baik secara kualitatif dan kuantitatif yang akan meningkatkan kerentanan terjadinya infeksi. ${ }^{24}$

Pada penelitian ini juga didapatkan bahwa insidensi TB paru lebih tinggi pada pasien yang bekerja sebagai petani $(28,13 \%)$, diikuti oleh ibu rumah tangga $(15,6 \%)$. Hal ini dapat dihubungkan dengan penelitian yang dilakukan oleh Mamane et al. $^{25}$ yang melaporkan bahwa terdapat peningkatan risiko gangguan pernapasan pada petani yang terpapar pestisida.

Pada penelitian ini distribusi insidensi TB pada subjek berdasarkan derajat PGKnya, didapatkan paling banyak pada derajat 5 yaitu 14 orang $(43,75 \%)$ dan 11 diantaranya tidak menjalani dialisis. Ostermann et al. ${ }^{8}$ melalui penelitian retrospektif melaporkan mayoritas pasien TB-PGK berada pada derajat 4 sampai 5 (67,5\%). Hal ini disebabkan adanya perubahan imunitas pada pasien PGK yang semakin memburuk pada derajat yang lebih lanjut. ${ }^{13}$ Selain itu, kadar ureum yang lebih tinggi pada pada pasien PGK yang tidak menjalani dialisis meningkatkan kerentanan infeksi.

Pada penelitian ini didapatkan insidensi TB paling banyak didapatkan pada pasien nefropati OAINS (66\%). Wu et al. ${ }^{26}$ melalui penelitian case-control melaporkan bahwa terdapat peningkatan risiko infeksi TB aktif pada pasien yang sering menggunakan OAINS tetapi pada penelitian tersebut tidak didapatkan bukti mengenai mekanisme penyebab antara OAINS dengan TB. Ostermann et al. ${ }^{8}$ melaporkan bahwa pasien PGK dengan koinfeksi TB paling banyak disebabkan oleh glomerulosklerosis/glomerulonefritis $(22,5 \%)$ namun tidak disebutkan hubungan antara PGK yang disebabkan oleh glomerulonefritis TB. $^{8}$

\section{SIMPULAN}

Berdasarkan hasil penelitian ini dapat disimpulkan bahwa mayoritas pasien PGK di RSUP Prof. Dr. R. D. Kandou Manado berjenis kelamin laki-laki, berusia 45-65 tahun, dan bekerja sebagai petani. Berdasarkan penyakit penyebab PGK-nya paling banyak disebabkan oleh nefropati OAINS. Mayoritas pasien PGK dengan derajat 5, sebagian di antaranya non dialisis.

\section{DAFTAR PUSTAKA}

1. Neuen BL, Chadban SJ, Demaio AR, Johnson DW, Perkovic V. Chronic kidney disease and the global NCDs agenda. BMJ Glob Heal. 2017;2(2):1-7

2. World Health Organization. WHO methods and data sources for global causes of death 2000-2016. Global Health Estimates Technical Paper WHO/HIS/ HSI/GHE/2016.3. Geneva: World Health Organization, 2018 Available from: http://www.who.int/ healthinfo/global_ burden_disease/GlobalCOD_method_20 00_2016.pdf.

3. Suwitra K. Penyakit ginjal kronik. In: Sudoyo A, Setiyohadi B, Alwi I, Simadibrata KM, Setiati S, editors. Buku Ajar Ilmu Penyakit Dalam (6th ed). Jakarta: InternaPublishing, 2014; p. 2159-65.

4. Riset Kesehatan Dasar (Riskesdas 2013) Laporan Nasional 2013. Jakarta: Badan Penelitian dan Pengembangan Kesehatan Departemen Kesehatan Republik Indonesia, 2013.

5. Global tuberculosis report 2018. Geneva: World Health Organization, 2018. Licence: CC BY-NC-SA 3.0 IGO.

6. Indonesian Renal Registry (IRR). 10th Report of Indonesian Renal Registry, 2017.

7. Abdelrahman M, Sinha AK, Karkar A. Tuberculosis in end-stage renal disease patients on hemodialysis. Hemodial Int. 2006;10(4):360-4.

8. Hu HY, Wu CY, Huang N, Chou YJ, Chang YC, Chu D. Increased risk of tuberculosis in patients with end-stage renal disease: A population-based cohort study in Taiwan, a country of high incidence of end-stage renal disease. Epidemiol Infect. 2014;142(1): 191-9.

9. Ostermann M, Palchaudhuri P, Riding A, Begum P, Milburn HJ. Incidence of tuberculosis is high in chronic kidney 
disease patients in South East England and drug resistance common. Ren Fail. 2016;38(2):256-61.

10. Girndt M, Sester U, Sester M, Kaul H KH. Impaired cellular immune function in patients with end-stage renal failure. Nephrol Dial Transpl. 1999;14:2807-10.

11. Kay N, Raij L. Immune abnormalities in renal failure and hemodialysis. Blood Purif. 1986;4:120-9.

12. Lim W, Kireta S, Russ G, Coates P. Uremia impairs blood dendritic cell function in hemodialysis patients. Kidney Int. 2007;71:1122-31.

13. Carrero JJ, Stenvinkel $P$. Inflammation in end-stage renal disease - what have we learned in 10 years? Semin Dial. 2010;23:498-509

14. Dobler CC, McDonald SP, Marks GB. Risk of tuberculosis in dialysis patients: A nationwide cohort study. PLoS One. 2011;6(12):1-6.

15. Hu HY, Wu CY, Huang N, Chou YJ, Chang YC, Chu D. Increased risk of tuberculosis in patients with end-stage renal disease: A population-based cohort study in Taiwan, a country of high incidence of end-stage renal disease. Epidemiol Infect. 2014;142(1):191-9.

16. Allotey $\mathbf{P}$, Gyapong $\mathbf{M}$. Gender in tuberculosis research. Int $\mathbf{J}$ Tuberc Lung Dis. 2008;12(7):831-6.

17. Nhamoyebonde S, Leslie A. Biological differences between the sexes and susceptibility to tuberculosis. J Infect Dis. 2014;209 (Suppl. 3).

18. Narasimhan P, Wood J, MacIntyre CR,
Mathai D. Risk factors for tuberculosis. Pulm Med. 2013;2013:1-11.

19. Li SY, Chen TJ, Chung KW, Tsai LW, Yang WC, Chen JY, et al. Mycobacterium tuberculosis infection of endstage renal disease patients in Taiwan: A nationwide longitudinal study. Clin Microbiol Infect. 2011;17(11):1646-52.

20. Sen N, Turunc T, Karatasli M, Sezer S, Demiroglu YZ, Oner Eyuboglu F. Tuberculosis in patients with end-stage renal disease undergoing dialysis in an endemic region of Turkey. Transplant Proc. 2008;40(1):81-4.

21. Pan WR, Suami H, Taylor GI. Senile changes in human lymph nodes. Lymphat Res Biol. 2008;6:77-83.

22. Linton PJ, Dorshkind $K$. Age-related changes in lymphocyte development and function. Nat Immunol. 2004;5:133-9.

23. Miller RA. Aging and immune function. Int Rev Cytol. 1991;124:187-215.

24. Valiathan R, Ashman M, Asthana D. Effects of ageing on the immune system: infants to elderly. Scand J Immunol. 2016;83(4):255-66.

25. Mamane A, Baldi I, Tessier JF, Raherison C, Bouvier G. Occupational exposure to pesticides and respiratory health. Eur Respir Rev. 2015;24:306-19.

26. Wu CW, Wu JY, Lee MTG, Lai CC, Wu IL, Tsai YW, et al. Risk of incident active tuberculosis disease in patients treated with non-steroidal anti-inflammatory drugs: A population-based study. BMC Pulm Med. 2017;17(1):1-8. 